\title{
EFFECT OF INFLATION AND PRICE INDEX ON EQUITY ASSETS
}

\author{
Ibram Pinondang Dalimunthe*), Ajeng Desni Lestari \\ Universitas Pamulang \\ ibram.pinondang86@gmail.com
}

\begin{abstract}
The purpose of this study is to determine the effect of inflation and the equity price index on the net asset value of the Islamic Fixed Income Mutual Funds registered with the Financial Services Authority for the period from from 2011 to 2016.

The type of search used is associative search. The data in this study are secondary historical data using Net Asset Value (NAV) and the share price index published by the Financial Services Authority (OJK), as well as inflation data published by Bank Indonesia for the period 2011-2016. The method used in this study uses regression analysis with panel data.

The results show that inflation has a negative and significant impact on the net asset value. The equity price index has a positive and significant influence on the net asset value. Inflation and the equity price index simultaneously have a significant effect on the net asset value of Sharia mutual funds.
\end{abstract}

Keywords: net asset value, inflation, equity price index, Islamic mutual funds.

\section{INTRODUCTION}

In the history of economic development, almost all countries have shown that one of the factors in the success of a country's economic development is a well-organized capital market. The capital market tries to raise public funds for development while increasing the sources of public savings. This means that the capital market participates in development, in general, by directly involving the community by investing its funds in healthy and wellmanaged companies.

Investments can be made in money market or capital market. Basically, the capital market and the money market are two parties that have a mission and the same objective acting in the same place, namely the financial market. These two parties are trying to help his country's economy to stay smooth and create prosperity and prosperity for the entire community of the country.

The role of capital markets is very important in terms of national economic development. Indeed, with the existence of the capital market, development finance can be available properly. The share of capital in production is one of the factors that determine the success and development of a business. With the capital market, companies easily obtain capital for their business by selling stocks or bonds.

Financial services authorities (OJK) continue to provide full support to stock market members to increase investor awareness of investment methods to build confidence in investment decisionmaking. This is intended to increase the investment activity of investors. 
Net Asset Value (NAV) is a measure of the return on investments of Sharia Mutual Funds. The net asset value is derived from the value of the relevant mutual fund portfolio.

According to Rizqollah (2016: 33), the net asset value (NAV) is obtained from the sum of the values of all portfolios consisting of cash, deposits, other money market instruments, bonds, shares and other financial market instruments and coupled with bills to brokers, dividends receivable, interest receivable and other receivables. Loans, liabilities to dealers, obligations for unpaid brokerage fees, fees of the custodian of unpaid fees and amortization of start-up costs are then reduced.

The development and growth of Islamic mutual funds between 2010 and 2014 has increased. But in 2015, the performance of the Islamic mutual fund industry declined. The Financial Services Authority (OJK) noted that total funds managed by Islamic mutual funds at the end of 2015 amounted to Rp.11.019 billion. This value decreased by $1.24 \%$ compared to the end of 2014 to reach Rp.11 158 billion. At the same time, the number of active Islamic mutual fund products increased by $25.68 \%$ at the end of 2015, rising to 93 Islamic Mutual Funds compared to the end of 2014, with 74 such funds. The share of funds managed by Islamic mutual funds represents only about $4.05 \%$ of total active mutual funds, which amounted to about Rp.271.969 billion by the end of 2015. While the share of the number of mutual funds Islamic investment accounts for only $8.52 \%$ of the total number of active mutual funds, about 1,091 mutual funds.

The development of Islamic mutual funds is inseparable from various internal and external factors in society. External factors in society come in the form of macroeconomic conditions of a country, such as changes in inflation rates. Changes in these factors can have a positive or negative impact on Islamic mutual funds. It is in the interest of investment managers to take this into account, especially as the value of net assets of Islamic mutual funds changes. it can be concluded that inflation is an increase in the overall price of goods

When the inflation rate is high, the Bank of Indonesia will increase the BI rate. Theoretically, increasing the $\mathrm{BI}$ rate will increase interest on bank loans. As interest rates rise, investors will choose alternative deposits with higher interest rates. As a result, stocks and bonds were sold, causing prices of stocks, bonds and mutual funds to plummet. The opposite applies when inflation is too low and interest rates fall. Investors will look for alternatives that offer higher returns than deposits, whether stocks or bonds. As a result, there is a strong demand for stocks and bonds, resulting in higher prices for stocks, bonds and mutual funds.

In addition to paying attention to the influence of macroeconomic variables on the performance of mutual funds, what is often used to see the performance of mutual funds is the comparison between the performance of the mutual fund and its comparison. According to Darmadji and Fakhruddin (2012: 129), the index serves as an indicator of market trends, which means that the movement of the index describes the market conditions at a given moment. Is the market active or stagnant? The movement of the index becomes an important indicator for investors to determine whether they will sell, hold or buy a stock or multiple stocks.

The basic explanation above has a research objective of whether inflation and the equity price index affect the net asset value of sharia mutual funds.

\section{LITERATURE REVIEW}

\subsection{Theory of the Agency}


The basic principle of this theory is that there is a working relationship between the party giving authority, namely the investor and the party receiving the authority (the agency), namely the manager. This theory is one of the theories that have emerged in the development of financial accounting research by adding aspects of human behavior in the form of economics. The theory of the agency that bases the contractual relations between shareholders/ owners and management/ managers is difficult to create because of conflicting interests.

\subsection{Theory of Inflation}

According to Sukirno (2012: 14), inflation can be defined as a process of rising prices that prevails in an economy. The rate of inflation differs from one period to another and from one country to another. Sometimes the inflation rate is low, below $2 \%$ or $3 \%$. Moderate inflation rates are between $4 \%-10 \%$. Very serious inflation rates can reach $10 \%$ or even $100 \%$ per year.

The types of inflation can be classified according to their severity as follows (Prasetyo, 2012: 198):

a. Creeping Inflation

Inflation is said to be low if price increases rise very slowly with a small percentage, less than $10 \%$ per year.

b. Galloping Inflation

It is said that a country experiences moderate inflation if the rate of inflation is between $10 \%$ and $30 \%$ per year.

c. High Inflation

Inflation is said to be high if the rate of inflation varies between $30 \%$ and $100 \%$ per year.

d. Hyperinflation

Hyperinflation can occur if the inflation rate is above $100 \%$ per year. If a country experiences hyperinflation, the community no longer has confidence in money, it prefers to exchange it for certain goods.
The results of the development of a research assumption that affects the net asset value of Sharia mutual funds, as follows:

H1: Inflation has a positive effect on the net asset value of Sharia investment funds.

$\mathrm{H} 2$ : The equity price index has a positive effect on the net asset value of Sharia investment funds.

H3: Inflation and the share price index have a simultaneous effect on the net asset value of sharia mutual funds.

\section{RESEARCH METHOD}

\subsection{Types of Research}

This study uses a panel data analysis, a combination of time series data covering the period from January 2011 to December 2016 and cross-section data.

The population of this study was 160 sharia mutual funds registered with the Financial Services Authority (OJK), while the selection of samples from this study was based on a purposive sampling, so that 4 companies with investment funds fixed-income sharia were obtained.

\subsection{Variables and Measures}

The independent variable in this study is inflation and the stock price index. The dependent variable used is the net asset value of Islamic Mutual Funds.

\subsubsection{Inflation}

The indicator used is the Consumer Price Index (CPI). Changes in the CPI from time to time indicate price movements in the sets of goods and services consumed by the public.

Rate of inflation $=\left[\frac{\left(\text { price }_{t}-\text { price }_{t-1}\right)}{\text { price }_{t-1}}\right] \times 100 \%$

\subsubsection{Stock Price Index}

According to Hadi (2015: 284), the equity price index is an indicator that shows movements in stock prices. The equity price index is a market trend that describes the market conditions in or out of business. Thus, the stock price index describes the performance of the shares 
both individually and cumulatively (market performance).

IHS $=\frac{\text { current price }}{\text { base hour price }} \times 100 \%$

\subsubsection{Net Asset Value of Sharia Investment Funds}

According to Hidayat (2012: 98), Islamic mutual funds are mutual funds operating in accordance with the provisions and principles of Islamic Sharia, in the form of contracts between investors as owners (sahib al-maal) and

investment managers as authentic representatives. and between the investment managers as representative of sahib al-maal and the users of the investment.

\section{RESULT AND DISCUSSION}

\subsection{Hausman Test}

Table 1 Hausman Test (Correlated Random Effect Test)

\begin{tabular}{|c|c|c|c|c|}
\hline \multicolumn{5}{|c|}{$\begin{array}{l}\text { Correlated Random Effects - Hausman Test } \\
\text { Pool: POOL } \\
\text { Test cross-section random effects }\end{array}$} \\
\hline Test Summary & & $\begin{array}{l}\text { Chi-Sq. } \\
\text { Statistic }\end{array}$ & Chi-Sq. d.f. & Prob. \\
\hline Cross-section random & & 0.000000 & 2 & 1.0000 \\
\hline \multicolumn{5}{|c|}{$\begin{array}{l}\text { * Cross-section test variance is invalid. Hausman statistic set to zero. } \\
\text { Cross-section random effects test comparisons: }\end{array}$} \\
\hline Variable & Fixed & Random & Var(Diff.) & Prob. \\
\hline $\begin{array}{c}\text { INFLATION? } \\
\text { IHS? }\end{array}$ & $\begin{array}{r}-0.068255 \\
0.801937\end{array}$ & $\begin{array}{r}-0.068255 \\
0.801937\end{array}$ & $\begin{array}{r}0.000000 \\
-0.000000\end{array}$ & $\begin{array}{r}1.0000 \\
\mathrm{NA}\end{array}$ \\
\hline
\end{tabular}

In Table 4.1 it can be seen that the results of the cross-section probability random effects model is more probability value are $1.0000>0.05$, so $\mathrm{H}_{0}$ is accepted. It can be concluded that the

\subsection{Normality Test}

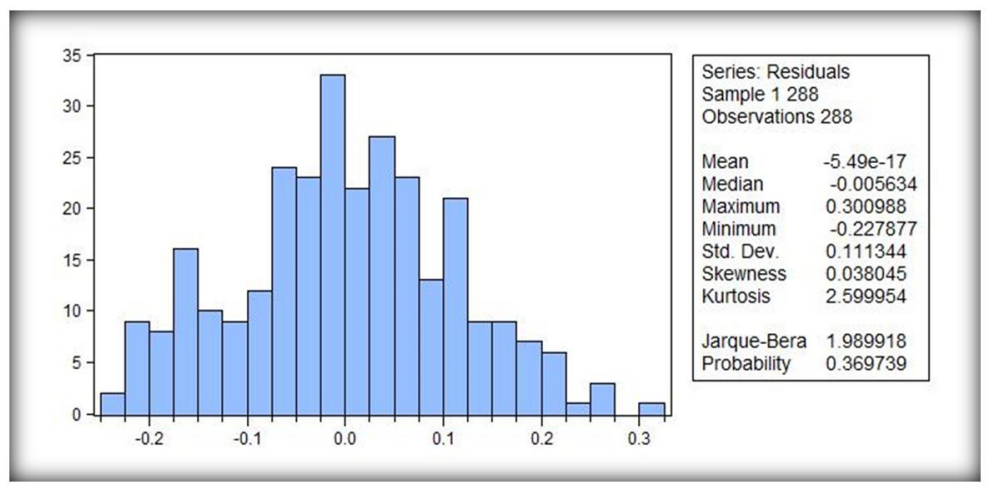

Figure 1 Histogram 
Figure 4.1 shows that the probability value of more than $5 \%$ is $0.369739>$ 0.05 , the data is normally distributed.

\subsection{Multikolinearity Test} Table 2 Multicollinearity Test

\begin{tabular}{|ccc|}
\hline & INFLATION & IHS \\
\hline \hline INFLATION & 1.000000 & -0.134341 \\
IHS & -0.134341 & 1.000000 \\
\hline
\end{tabular}

Table 4.2 shows that the correlation coefficient between the independent variables is -0.133441 . Means it is always less than 0.90 and the data in this study are free from multicollinearity

\subsection{Autocorrelation Test}

Table 3 Autocorrelation Test

\begin{tabular}{|llll|}
\hline Breusch-Godfrey Serial Correlation LM Test: & \\
\hline \hline F-statistic & 0.810685 & Prob. F(2,282) & 0.4456 \\
Obs*R-squared & 1.640684 & Prob. Chi-Square(2) & $\mathbf{0 . 4 4 0 3}$ \\
\hline \hline
\end{tabular}

Table 4.3 shows that the probability value of Obs * R-squared is $0.4403>0.05(\alpha$ value), indicating that the data do not contain autocorrelation problems.

\subsection{Heteroscedasticity Test}

Table 4.4 Heteroscedasticity Test

\begin{tabular}{|c|c|c|c|}
\hline \multicolumn{4}{|c|}{ Heteroskedasticity Test: White } \\
\hline F-statistic & 1.135497 & Prob. F(2,285) & 0.3227 \\
\hline Obs*R-squared & 2.276758 & Prob. Chi-Square(2) & 0.3203 \\
\hline Scaled explained SS & 1.783607 & Prob. Chi-Square(2) & 0.4099 \\
\hline
\end{tabular}

The results showed that there was no problem of heteroscedasticity because the probability value of $\mathrm{Obs} * \mathrm{R}$ squared was $0.3203>0.05$ ( $\alpha$ value $)$

\subsection{Coefficient of Determination Test (R2)}

Table 4.5 Coefficient of Determination of the Random Effect Model

\begin{tabular}{|llll|}
\hline Dependent Variable: NAV? & & \\
\hline \hline R-squared & 0.597266 & Mean dependent var & 0.744143 \\
Adjusted R-squared & $\mathbf{0 . 5 9 4 4 4 0}$ & S.D. dependent var & 0.120276 \\
S.E. of regression & 0.076596 & Sum squared resid & 1.672095 \\
F-statistic & 211.3313 & Durbin-Watson stat & 0.245916 \\
Prob(F-statistic) & 0.000000 & & \\
\hline \hline
\end{tabular}

Table 4.5 of the adjusted R-squared value formed in this study is 0.594440 , which means that the independent variables (inflation and stock price index) has a capacity to explain the dependent variable (value of the net assets) of $59.44 \%$ and the remaining $40.56 \%$. explained by other variables not included in this model. 


\subsection{F Statistics Test}

Table 6 Statistical Test of the Modality of Effective F

\begin{tabular}{|llll|}
\hline $\begin{array}{l}\text { Dependent Variable: NAV? } \\
\text { Total pool (balanced) observations: } 288\end{array}$ & \\
\hline \hline R-squared & 0.597266 & Mean dependent var & 0.744143 \\
Adjusted R-squared & 0.594440 & S.D. dependent var & 0.120276 \\
S.E. of regression & 0.076596 & Sum squared resid & 1.672095 \\
F-statistic & 211.3313 & Durbin-Watson stat & 0.245916 \\
Prob(F-statistic) & $\mathbf{0 . 0 0 0 0 0 0}$ & & \\
\hline \hline
\end{tabular}

Table 6 Random Effect Indicate whether the value of $\mathrm{F}$ is 211.3313 with a probability of 0.000000 and the value of $\mathrm{F}_{\text {table }}$ with df: $\alpha,(\mathrm{k}-1)$, (nk) or 0.05 , (31), (288-3) amounting to 3.027443. So the result is $211.3313>3.027443 \mathrm{H}_{0}$ is rejected and $\mathrm{H}_{\mathrm{a}}$ is accepted. The significance probability value of 0.0000 also indicates a value less than the value at a predetermined significance level which is $0.05(0.0000<0.05)$. We can therefore conclude that the independent variables (inflation and equity price index) simultaneously have a significant effect on the dependent variable (value of net assets).

\section{8 t Statistics Test}

a. Effect of inflation on net asset value Inflation shows a $t_{\text {account }}$ of -4.603749 . When compared with $t_{\text {table }}$ at a significance level of 0.05 with $\mathrm{df}=$ $(\alpha: 2) \quad(\mathrm{nk})=(0.05: 2) \quad(288-3)=$ (0.025) (285) of 2.253307, then $t_{\text {count }}$ is greater than $t_{\text {table }}(-4.603749>$ 2.253307). The significance value of 0.0000 also indicates a value less than the value of the predetermined significance level of $0.05(0.0000<$ $0.05)$. It can therefore be concluded that the inflation variable has a partially negative and significant effect on the value. Net Assets of Sharia Pooled Funds for the Period 2011-2016.

b. Effect of the share price index on the net asset value

IHS shows a $t_{\text {count }}$ of 19.23657 relative to the table at a significance level of 0.05 with $\mathrm{df}=(\alpha: 2)(\mathrm{nk})=$ $(0.05: 2)(288-3)=(0.025) \quad(285)$
$2,253,307$ then $t_{\text {count }}$ is greater than $t_{\text {table }}(19,23657>2,253307)$. The significance value value of 0.0000 also indicates a value less than the value of the specified significance level of $0.05(0.0000<0.05)$. It can therefore be concluded that the stock price index (IHS) variable has a partially positive and significant effect on the net asset value of sharia mutual funds for the period 20112016.

4.9 The Data Panel Regression Analysis Test

The interpretations of the researchers for each company are as follows:

1. BNI Syariah Foundation (BNI-AM Dana Dompet Dhuafa)

$\mathrm{NAV}=-0,014027-0,068255$ Inflation $+0,801937$ IHS $+\mathrm{e}$

a. The constant value of -0.014027 shows that if the independent variable consisting of inflation and the stock price index (IHS) is 0 , the value of the net asset value (NAV) is $-0.014027 \%$.

b. The inflation coefficient is 0.068255 , which indicates that if the value of inflation increases by $1 \%$, the NAV will decrease by $0.068255 \%$.

c. The coefficient of the stock price index (IHS) is 0.801937, which indicates that the value of the IHS has increased by $1 \%$, which increases the value of the NAV by $0.801937 \%$.

2. MNC Dana Syariah 
$\mathrm{NAV}=-0,118690-0,068255$ Inflation $+0,801937$ IHS $+\mathrm{e}$

a. The constant value of -0.1118690 shows that if the independent variable composed of inflation and the stock price index (IHS) is 0 , the value of the net asset value (NAV) is $-0.1118690 \%$.

b. The value of the inflation coefficient is -0.068255 , which indicates that if the value of inflation increases by $1 \%$, the net asset value will decrease by $0.068255 \%$.

c. The coefficient of the stock price index (IHS) is 0.801937, which indicates that the value of the IHS has increased by $1 \%$, which increases the value of the NAV by $0.801937 \%$.

3. I-Hajj Syariah Fund

$\mathrm{NAV}=0,028562-0,068255$ Inflation $+0,801937$ IHS $+\mathrm{e}$

a. The constant value of 0.028562 indicates that if the independent variable consisting of inflation and the stock price index (IHS) equals 0 , the value of the net asset value (NAV) is $0.028562 \%$.

b. The value of the inflation coefficient is -0.068255 , which indicates that if the value of inflation increases by $1 \%$, the net asset value will decrease by $0.068255 \%$.

c. The coefficient of the stock price index (IHS) is 0.801937, which indicates that the value of the IHS has increased by $1 \%$, which increases the value of the NAV by $0.801937 \%$.

4. Mandiri Investa Dana Syariah

$\mathrm{NAV}=0,104163-0,068255$ Inflation $+0,801937$ IHS $+\mathrm{e}$

a. The constant value of 0.104163 indicates that if the independent variable consisting of inflation and the stock price index (IHS) is 0 , the value of the net asset value (NAV) is $0.104163 \%$. b. The value of the inflation coefficient is -0.068255 , which indicates that if the value of inflation increases by $1 \%$, the net asset value will decrease by $0.068255 \%$.

c. The coefficient of the stock price index (IHS) is 0.801937, which indicates that the value of the IHS has increased by $1 \%$, which increases the value of the NAV by $0.801937 \%$.

\subsection{Discussion}

1. Influence of Inflation on the Net Asset Value

The results of the study show that inflation has a negative and significant impact on the net asset value of sharia mutual funds for the period 2011-2016. When interest rates rise, investors will choose alternative deposits with higher interest rates. As a result, equity and bond instruments were sold, leading to a fall in the prices of stocks, bonds and mutual funds. Conversely, when interest rates are lowered, investors will look for alternatives that offer higher investment returns than deposits, ie stocks and bonds. As a result, there is a strong demand for stocks and bonds, resulting in higher prices for stocks, bonds and mutual funds. The increase in the inflation rate will have a negative impact on investment and, conversely, a decrease in the inflation rate will have a positive impact on investment. This is not consistent with the hypothesis and research conducted by Febrian (2015) and Amsi (2016), so the results of this study reject most of the findings of previous studies that inflation influences positive and significant impact on the net asset value of Sharia mutual funds.

2. Effect of the Share Price Index on the Net Asset Value

The results showed that the Equity Price Index (IHS) had a significant 
positive effect on the net asset value of sharia mutual funds for the period 2011-2016. The equity price index has capital market functions as a profit level indicator and benchmark for a portfolio's performance. By increasing the equity price index shown in the Islamic Index of Jakarta (JII), mutual funds are increasing indirectly with a higher-thancomparative value of return, which indicates that the return of mutual funds is good. Conversely, when the stock price index declines, Islamic mutual funds also decline. For example, trading in Shari'a capital market instruments, namely sharia mutual funds in general, has relatively followed the evolution of capital market prices, which translates into a movement consistent with the stock price index.

This is consistent with the hypothesis and research conducted by Tenggar (2014) and Iza (2016) that the Djakarta Islamic Index (JII) has a positive and significant effect. The results of this study are therefore accepted.

3. Effect of Inflation and the Price Index on the Value of Net Activity The results show that inflation and the share price index have a significant effect on the net asset value.

This is what Rena (2015) has done on the fact that inflation and the Islamic index (Islamic Index of Jakarta) simultaneously affect the value of net assets (NAV), which means that the size of the The value of the net assets of Islamic mutual funds is influenced by the Islamic Index (Islamic Index of Jakarta). in addition to other factors outside the research.

\section{CONCLUSION}

On the basis of the results of the analysis, the conclusions can be drawn as follows:

1. In part, the test results show that inflation has a significant negative effect on the net asset value of Islamic fixed income mutual funds.

2. The equity price index has a positive and significant impact on the net asset value of fixed income mutual funds.

3. At the same time, it shows that inflation and the equity price index have an effect on the dependent variable of the net asset value of mutual funds and that they are significant. follows:

Suggestions can be given as

1. Inflation

The results showed that inflation had a negative effect on the net asset value of Sharia mutual funds, the investment manager should reconsider the decision to place funds from the investment community in the appropriate securities portfolio so to increase the results of Islamic mutual funds held.

2. Stock price index (Islamic Index of Jakarta)

The equity price index with research results showing that the Jakarta Islamic Index has a positive and significant effect on the net asset value of sharia mutual funds. Investors can use the Jakarta Islamic Index as a benchmark for investment decision-making. 


\section{REFERENCES}

-. (1995). Pasar Modal Indonesia. -: Undang-undang No. 8 Tahun 1995.

-. (2001). Pedoman Pelaksanaan Investasi untuk Reksa Dana Syariah. -: Fatwa DSN-MUI No. 20/DSN-MUI/IV/2001.

-. (2002). Obligasi Syariah. -: Fatwa DSN-MUI No. 32/DSNMUI/X/2002.

-. (2015). Penerbitan dan Persyaratan Reksa Dana Syariah. -: Peraturan Otoritas Jasa Keuangan No. 19/POJK/04/2015.

Ainur Rahman, I. M. (2015). Pengaruh Inflasi, Nilai Tukar Rupiah, BI Rate Terhadap Net Asset Value Reksa Dana Saham Syariah. Jurnal Ekonomi Syariah (Teori \& Terapan), 986-1001.

Ali, K. (2012). Analisis Pengaruh Variabel Makroekonomi terhadap Reksa Dana Syariah di Indonesia. Bogor: Fakultas Ekonomi dan Manajemen Institut Pertanian Bogor.

Arikunto, S. (2013). Prosedur Penelitian: Suatu Pendekatan Praktik. Jakarta: Rineka Cipta.

Aviva, I. N. (2016). Pengaruh Jumlah Uang Beredar (JUB), Sertifikat Bank Indonesia Syariah (SBIS), dan Jakarta Islamic Index (JII) terhadap Nilai Aktiva Bersih Reksa Dana Syariah Periode 2011-2015. Indonesia Banking School, 1-14.

Ghazali, I. (2013). Aplikasi Analisis Multivariate dan Ekonometrika: Teori, Konsep dan Aplikasi dengan Eviews 8. Semarang: Universitas Diponegoro.

Gujarati，D. N. (2012). Dasar-dasar Ekonometrika Buku 1. Surakarta: Salemba Empat.

Hadi, N. (2015). Pasar Modal. Yogyakarta: Graha Ilmu.
Hakim, S. (2016). LKNB: Lembaga Keuangan Non Bank. Depok: STEI SEBI.

Hidayat, T. (2012). Buku Pintar Investasi Syariah. Jakarta: Media Kita.

Nandari, H. U. (2017). Pengaruh Inflasi, Kurs dan BI Rate terhadap Nilai Aktiva Bersih (NAB) Reksadana Syariah di Indonesia (Periode 2010-2016). An-Nisbah, 51-73.

Nasikhah, A. (2017). Pengaruh Nilai Tukar Rupiah (Kurs), Sertifikat Bank Indonesia Syariah (SBIS), dan Jakarta Islamic Index (JII) terhadap Nilai Aktiva Bersih (NAB) Reksa Dana Manulife Syariah Sektoral Amanah Tahun 2010-2016. Tulung Agung: IAIN Tulung Agung.

Nugraha, B. A. (2014). Analisis Pengaruh Kepemilikan Manajerial, Kepemilikan Institusional, DER, dan ROA terhadap Nilai Perusahaan pada Perusahaan Manufaktur di Bursa Efek Indonesia Periode 20102012. Semarang: Universitas Diponegoro.

Pangayoman, T. (2014). Pengaruh Inflasi dan Indeks Syariah (Jakarta Islamic Index) terhadap Kinerja Reksa Dana Syariah. Yogyakarta: Fakultas Agama Islam Universitas Muhammadiyah Yogyakarta.

Rafiah, S. P. (2016). Pengaruh Inflasi dan Nilai Tukar Rupiah terhadap Net Asset Value (NAV) Reksa Dana Syariah di Indonesia Tahun 2013-2015. Surabaya: Fakultas Ekonomi dan Bisnis Islam IAIN Tulungagung.

Rizqollah, A. (2016). Analisis Pengaruh Variabel Inflasi dan Kapitalisasi Jakarta Islamic Index (JII) Terhadap Nilai Aktiva Bersih 
(NAB) Reksa Dana Syariah di Indonesia Periode 2011-2014. Palembang: Universitas Islam Negeri Raden Fatah.

S, R. A. (2015). Analisis Pengaruh Sertifikat Bank Indonesia Syariah (SBIS), Inflasi dan Jakarta Islamic Index (JII) terhadap Nilai Aktiva Bersih (NAB) Danareksa Syariah Berimbang. Palembang: UIN Raden Fatah.

Sarwono, J. (2016). Prosedur-prosedur Analisis Populer Aplikasi Riset Skripsi dan Tesis dengan Eviews. Jakarta: Gava Media.

Setyarini, F. D. (2015). Pengaruh SBIS, Inflasi, Nilai Tukar Rupiah, Jumlah Uang Beredar dan IHSG terhadap Nilai Aktiva Bersih Reksa Dana Syariah Periode 2009-2013. Yogyakarta: IAIN Sunan Kalijaga.

Sugiyono. (2015). Metode Penelitian Kuantitatif Kualitatif dan $R \& D$. Bandung: Alfa Beta.

Oktober 2017)
Sukirno, S. (2012). Makroekonomi Teori Pengantar. Jakarta: Rajawali Pers.

Sukirno, S. (2013). Makroekonomi Teori Pengantar. Jakarta: Rajawali Pers.

Tjiptono Darmadji, H. M. (2012). Pasar Modal di Indonesia. Jakarta: Salemba Empat.

Winarno, W. W. (2015). Analisis Ekonometrika dan Statistika dengan Eviews. Yogyakarta: UPP STIM YKPN.

Wiradiyasa, I. (2015). Analisis Pengaruh Inflasi, Suku Bunga SBI, dan Kurs terhadap Kinerja Reksadana Syariah di Indonesia (Periode 2010-2014). Jurnal Ilmiah Mahasiswa FEB Universitas Brawijaya.

http://www.bps.go.id (diakses, 1 November 2017)

http://www.idx.co.id (diakses, 7 Desember 2017)

http://www.ojk.go.id (diakses, 5 